УДК 373.3/.5.091.33:004.4’416

Горошкіна Олена Миколаївна

доктор педагогічних наук, професор, провідний науковий співробітник відділу профільного навчання Інституту педагогіки НАПН України, м. Київ, Україна

ORCID ID 0000-0002-0378-888X

olenagoroshkina@gmail.com

Греб Марія Михайлівна

доктор педагогічних наук, професор, завідувачка кафедри української мови та славістики

Бердянський державний педагогічний університет, м. Бердянськ, Україна

ORCID ID 0000-0003-2874-7985

marygreb@i.ua

Горошкін Ігор Олександрович

кандидат педагогічних наук, старший науковий співробітник відділу навчання іноземних мов

Інститут педагогіки НАПН України, м. Київ, Україна

ORCID ID 0000-0003-2964-4518X

igorgoroshkin@gmail.com

Караман Станіслав Олександрович

доктор педагогічних наук, професор, завідувач кафедри української мови

Київський університет імені Бориса Грінченка, м. Київ, Україна

ORCID ID 0000-0003-3186-375X

stanislavkaraman@gmail.com

\title{
ФУНКЦIÏ QR-КОДІВ У СТРУКТУРІ ПІДРУЧНИКА УКРАЇНСЬКОЇ МОВИ
}

Анотація. У статті розглянуто проблему використання QR-кодів як складника сучасного підручника. Обгрунтовано актуальність уведення QR-кодів до змісту підручників української мови. Уточнено визначення QR-коду, під яким визначено компактний носій навчальної інформації обсягом близько трьох тисяч байт, закодованої за допомогою спеціальних програм або сервісів і графічно представленої як чорно-білий або кольоровий квадрат. Установлено, що QR-код уможливлює розширення й поглиблення теоретичних відомостей із навчального предмета. У підручниках української мови матеріали, вміщені на QR-кодах, розширюють і поглиблюють теоретичні відомості й дидактичний матеріал, сприяють удосконаленню орфоепічних, граматичних, правописних умінь і навичок учнів, виконують функцію контролю, пропонуючи тестовий та інший матеріал для встановлення рівня сформованості знань, умінь і навичок учнів. Визначено й обгрунтовано функції QRкодів у структурі підручників української мови - мотиваційну, інформаційну, розвивальну, виховну, рефлексійну, контрольну. Здійснено аналіз змісту підручників української мови для 10 класу та рукопису підручника для 11 класу, що містять QR-коди. Наведено відомості про експериментальну перевірку ефективності застосування QR-кодів, у процесі якої учні експериментальних класів систематично залучалися до роботи з QR-кодами, уміщеними в підручнику української мови, що передбачали опрацювання теоретичних відомостей, які розширювали й поглиблювали зміст підручника, виконання творчих, дослідницьких завдань, що спонукали учнів до спостережень над мовою, виконання вправ на редагування, тестових завдань. Визначено принципи відбору теоретичного матеріалу для QR-кодів, до яких віднесено доступність матеріалу, його комунікативну значущість, новизну, емоційність, роль у формуванні предметної компетентності учнів.

Наведено конкретні приклади кодування інформації в підручниках української мови: теоретичних відомостей, матеріалів засобів масової інформації (інтерв'ю, телепередач, виступів) для аналізу їх учнями, тестових завдань, прикладів правильних відповідників девіантних текстів, запропонованих учням для редагування тощо.

Ключові слова: QR-код; підручник української мови; засоби навчання; застосування QRкоду; функції QR-кодів; освітній процес; учні старших класів. 


\section{1. ВСТУП}

Постановка проблеми. Якісні зміни технічного забезпечення сучасного освітнього процесу зумовлюють розширення можливостей його суб'єктів здобувати, поглиблювати й трансформувати інформацію, необхідну для розв'язання практичних завдань у навчальних і позанавчальних ситуаціях. Це викликає появу нових підходів до організації уроку, комбінування методів, прийомів і засобів навчання. Традиційно інформатизацію й комп'ютеризацію пов'язували з наявністю комп'ютерних класів у закладах освіти, однак із появою гаджетів відбувається стрімке розширення функцій технологічного забезпечення освітнього процесу. Важливим засобом навчання став QRкод - складник шкільних підручників нового покоління. Зашифрована в ньому інформація уможливлює розширення й поглиблення теоретичних відомостей із навчального предмета, удосконалення загальнонавчальних та предметних умінь i навичок учнів; пропоновані контрольно-корекційні завдання забезпечують реалізацію функції контролю, тобто дають змогу оперативно й об'єктивно встановити рівні сформованості знань, умінь і навичок здобувачів освіти. Водночас зазначимо, що в українській педагогічній науці ще не розроблено належним чином методику оптимального застосування QR-кодів на уроках і в самостійній роботі учнів. Окремого вивчення потребують принципи відбору інформації для QR-кодів та способи репрезентування іiї в навчальних виданнях, оскільки, як свідчить аналіз змісту шкільних підручників, автори здебільшого хаотично застосовують QR-коди. Тож зазначене вказує на необхідність визначення функцій QR-кодів та розроблення ефективних механізмів їх застосування в шкільних підручниках української мови.

Аналіз останніх досліджень і публікацій. 3-поміж багатьох проблем і викликів, що стоять перед сучасною українською освітою, є такі, без належного розв'язання яких не будуть працювати жодна концепція навчання, жодна освітня технологія. До таких належить проблема розроблення шкільних підручників нового типу - за змістом, структурою, функціями, способами репрезентації навчального матеріалу.

Опрацювання дидактичної й лінгводидактичної літератури засвідчує, що окресленій проблемі присвячено праці багатьох дослідників. На різних часових відтинках було актуалізовано окремі ï̈ аспекти: принципи конструювання підручників, критерії добору навчального матеріалу, вплив підручників на розвиток учнів тощо. Останнім часом українські й зарубіжні дослідники зосереджені на вивченні особливостей конструювання підручників з різних навчальних предметів. У контексті порушеної проблеми особливий інтерес становлять праці вчених (Н. Басай, І. Бім, Н. Бориско, О. Коломінова, М. Пентилюк, Т. Полонська, В. Редько, Garton S., Copland F., Janet Enever, Muñoz C. та ін.), присвячені особливостям побудови підручників. Оскільки спілкування державною мовою належить до переліку ключових і предметних компетентностей учнів, вважаємо логічним вивчити особливості побудови підручників, що забезпечують опанування предмета.

Науковці визначили основні функції, принципи побудови підручників української мови (Н. Бондаренко, А. Ярмолюк та ін.), критерії відбору навчального матеріалу (О. Біляєв, Л. Мацько, М. Пентилюк та ін.), соціокультурний потенціал (Н. Голуб, В. Загороднова, Д. Кобцев, М. Пентилюк, Л. Попова та ін.). Окремі аспекти змісту підручників висвітлено в розвідках Н. Басай, Т. Капелюшної, В. Плахотника, Т. Полонської, В. Редька та ін.; як засіб мотивації навчальної діяльності учнів розглядають підручник І. Бім, В. Редько та ін. Водночас відкритою залишається проблема пошуку ефективних шляхів підвищення ефективності шкільного підручника .

У сучасних соціокультурних реаліях не втрачає актуальності думка С. Карамана i В. Тихоші: „Підручник - один із найскладніших жанрів навчальної літератури. 
Складність полягає в тому, що перед авторами стоїть багатоаспектна мета, для здійснення якої потрібно врахувати й пов'язувати в єдине ціле безліч різнорідних вимог - мовних, методичних, соціальних, психологічних, українознавчих тощо" [1]. Такі вимоги стоять перед авторами підручників.

Услід за В. Редьком визначаємо підручник не тільки і не стільки плодом індивідуальної роботи автора, скільки продуктом дидактичної та методичної парадигми свого часу [2]. Тобто підручник має відповідати на соціальні виклики, бути засобом мотивації учнів до навчання предмета, формування в них ключових і предметної компетентностей. Це й зумовлює пошук ефективних шляхів удосконалення змісту і структури підручника, розширення його функцій.

На початку XXI століття збільшено питому вагу наукових досліджень, присвячених упровадженню інформаційно-комунікаційних засобів навчання в освітній процес (В. Биков, I. Галузо, Ю. Жук, Г. Корицька, О. Кучерук, А. Лукомський, Л. Попова та ін.). Привертають увагу праці, у яких розкрито особливості створення й застосування електронного підручника (О. Башмаков, I. Башмаков, В. Беспалько, Н. Морзе, Н. Семенів, Ю. Шепетко та ін.) у закладах освіти. Крім того, останнім часом в інтернетних джерелах істотно збільшено кількість блогів учителів-практиків, у яких запропоновано методичні рекомендації 3 вивчення окремих навчальних тем. Узагальнення висловлених тверджень і думок дало змогу зробити висновок, що педагоги останнім часом дедалі більше використовують електронні засоби навчання, що зумовлює актуальність опанування нових інформаційних технологій в освітньому процесі та визначення їх дидактичних і специфічних функцій.

У рекомендаціях Всесвітньої організації ЮНЕСКО зазначено, що ринок мобільних пристроїв великий, щодня зростає доступність їх для всіх верств населення, що робить пристрої найбільш популярними засобами IКТ [3]. Цей висновок підтвердили й результати опитування учнів, проведені у трьох міських школах Києва та Бердянська. Пересічно у 96 \% респондентів є смартфон, за цих обставин майже 44 \%, крім смартфона, мають інші мобільні пристрої - планшет, нетбук. Відсоток старшокласників, які використовують свої ноутбуки або планшети, комп'ютери вдома, становить $97 \%$, з них $75 \%$ - під час виконання домашніх завдань. Це й зумовлює введення електронних засобів навчання, зокрема QR-кодів, у сучасний освітній процес.

На сьогодні 3-поміж дослідників немає одностайності стосовно термінологічного статусу QR-коду: - його визначають як засіб, метод, прийом, технологію навчання. B. Бузько, Ю. Счкало потрактовують QR-код як елемент мобільного інформаційноосвітнього середовища й обгрунтовують доцільність його застосування в процесі навчання фізики [4, с. 39]. I. Галузо та А. Лукомський, досліджуючи використання QRкодів в освітній діяльності, слушно зауважують, що «застосування електронних засобів в освіті необхідно розглядати як педагогічний прийом, що розширює можливості навчання» [5]. Така неоднозначність не сприяє забезпеченню термінологічної чіткості й створює перешкоди для проведення лінгводидактичних досліджень. Студіювання наукових праць дало змогу уточнити визначення QR-коду, під яким розуміємо компактний носій навчальної інформації обсягом близько трьох тисяч байт, закодованої за допомогою спеціальних програм або сервісів й графічно представленої як чорно-білий або кольоровий квадрат.

Аналіз змісту навчальних книжок переконав, що застосування QR-кодів у підручниках української мови відповідає сучасним вимогам до здобування й поширення інформації, є зручним для користувача - завдяки установленим на смартфон чи планшет програмам і додаткам для ідентифікації QR-кодів учні охоче й легко розшифровують закодовану інформацію. Автори вважають QR-коди органічним 
складником підручників, оскільки чітко окреслено тенденцію до збільшення їх кількості та розширення змістового наповнення

Вивчення змісту рукописів підручників української мови, які пройшли поточного року конкурсний відбір, показує, що для 11 класу вчителі обрали однакову кількість книжок: 6-для навчання української мови (з них 2 - профільного рівня, 4 - рівня стандарт). Усі підручники української мови профільного рівня мають QR-коди, рівня стандарт лише 2 підручники. Звідси випливає припущення: 3 огляду на те, що чинна програма профільного рівня передбачає опанування більшого обсягу навчального матеріалу, на вивчення предмета відведено більшу кількість годин, QR-код стає інструментом оптимізації структурно-змістового наповнення навчальної книжки.

Оскільки розглядаємо QR-код як складник сучасного підручника - засобу навчання, то цілком логічно вважати його засобом навчання, що розширює пізнавальнорозвивальний потенціал підручника, сприяє посиленню інтересу учнів до опанування предмета, оскільки забезпечує індивідуалізацію та диференціацію навчання, а також уможливлюе організацію самостійної роботи учнів. У цьому контексті й будемо визначати функції QR-кодів як складника сучасних шкільних підручників української мови. 3 огляду на те, що QR-код $\epsilon$ лише піктограмою, яка графічно позначає покликання на відповідний інформаційний ресурс, визначати його функції можна умовно, маючи на увазі функції інформаційного масиву, закодованого QR-кодом. Зазначимо, що їх кілька 3 огляду на зміст, мету, спосіб репрезентування поданої інформації. Тож до цих функцій відносимо мотиваційну, інформаційну, розвивальну, виховну, рефлексійну, контрольну.

Психологи доводять, що людина активно долучається до будь-якої діяльності за умови наявності в неї відповідних мотивів для їі реалізації, тобто учень виконує вправи й завдання, якщо мотивований на це. О. Сергєєнкова і Ф. Подшивайлов обгрунтовують, що «чинник мотивації для навчання $є$ важливішим, ніж чинник інтелекту» [6]. Мотиви відображають потреби, актуальні для особистості на певному етапі навчання. О. Малихіна зазначає, що постійним стимулом мотивації навчання є задоволення від самої діяльності, що має бути забезпеченим радістю досягнення результату, яка може перетворитися на постійну внутрішню потребу, норму [7].

Мотиваційна функція QR-коду забезпечується передусім добором таких завдань, що сприяють створенню позитивного емоційного тла, формуванню в учнів упевненості в досягненні очікуваних результатів, стійкого бажання навчатися. Це зумовлює розміщення на QR-кодах навчальних кросвордів, творчих та інших цікавих для учнів завдань. Як засвідчують результати анкетування, проведеного 3-поміж учнів десятих класів (анкетуванням було охоплено 155 осіб), вони позитивно сприймають ігрові завдання (72 учні зазначили, що їм подобаються квести, які застосовують на уроках української мови, 51 респондент зазначив, що необхідно додати більше ілюстрованих вправ, 33 зазначили, що їм до вподоби кросворди). Крім того, значна частина десятикласників (86 осіб) вважає, що необхідно винести на QR-коди більше завдань для підготовки до ЗНО. 3 цього випливає, що введення навчального матеріалу, зорієнтованого на підготовку старшокласників до ЗНО, підвищить інтерес учнів до навчальної книжки.

Оскільки обсяг підручника не дозволяє вмістити значні масиви мовознавчих відомостей, матеріалів для редагування, тестів та інших завдань, доцільно їх розмістити, скориставшись QR-кодами. Такий спосіб викладу навчальних матеріалів спрямований на ціннісно-емоційний розвиток учнів, формування в них внутрішньої мотивації, осмислення дієвості кожного слова у тексті (впливовість слова, словаконфліктогени, доцільність, естетика слова тощо).

Інформаційна функція QR-коду реалізована передусім у розширенні меж шкільного підручника. Це дає змогу подати більше різноманітної інформації й, 
відповідно, сприяє кращому засвоєнню навчальних відомостей. Загальновідомо, що традиційний паперовий підручник має відповідати жорстким вимогам щодо обсягу, ваги. Це дещо обмежує авторів у доборі варіативності вправ для різних категорій здобувачів освіти. Перспективним вважаємо матричний принцип доповнення підручника текстовим дидактичним матеріалом, коли учням запропоноване одне спільне завдання, а вони виконують його на матеріалі різних за тематикою текстів (залежно від уподобань та інтересів у 5-8 класах, або від орієнтування на майбутню професію - у 9-11 класах), представлених на QR-кодах. Або ж учні - члени малої академії наук (МАН) - можуть отримати додаткові знання про видатних мовознавців, лексикографічні й довідкові видання, цікаві методично адаптовані відомості 3 сучасного мовознавства тощо. У контексті змін до «Українського правопису» на QRкодах доцільно розмістити відповідну інформацію, що уможливить сприймання учнями мови як динамічного явища, яке постійно розвивається. 3 огляду на це QR-код можна вважати інформаційним кейсом для учнів.

Усе це зумовлює виокремлення показників визначення інформативності QR-коду, до яких уналежнюємо адекватність відображення мовознавчої теорії й доступність іiі для учнів. Загалом добір матеріалів для QR-кодів як складника підручників української мови доцільно скеровувати на показники рівнів сформованості предметної та ключових компетентностей учнів: знаннєвий, діяльнісний, ціннісний, емоційний та поведінковий, що органічно доповнюють структуру підручника української мови. Обов’язковим елементом сучасного підручника української мови мають бути покликання на інші інформаційні джерела - словники, текстові масиви, відеоролики, а також різноманітні засоби унаочнення, наприклад: хмари тегів, моделі, схеми, таблиці, колажі тощо.

У сучасних умовах підручник стає засобом розвитку дитини, інструментом управління освітньою діяльністю учнів, навігатором у динамічних інформаційних потоках, засобом залучення суб'єктів освітнього процесу до інформаційного середовища. У цьому контексті розвивальна функція QR-коду полягає в тому, що закодовані в ньому навчальні матеріали сприяють розвиткові в учнів стійкої мотивації, інтересу до предмета, а також їніх особистісних якостей. Це зумовлює ретельний відбір матеріалів для QR-кодів з урахуванням принципів новизни, доступності, емоційності. Матеріал доцільно подавати в цікавій і доступній для учнів формі, переконувати їх у важливості тієї чи тієї теми, учити здобувати знання самостійно 3 різних джерел, працювати 3 інформаційними масивами (скорочувати, розширювати, трансформувати тощо), стимулювати розумову активність суб'єктів освітнього процесу. У працях Г.Граник доведено необхідність урізноманітнення навчального матеріалу з використанням засобів образності для кращого сприймання, ілюстрування теоретичних положень за допомогою малюнків, схем, таблиць [8]. Тож у підручнику навчальний матеріал може бути поданий текстом, a на QR-коді - як таблиця або навпаки, що забезпечуватиме краще сприймання його учнями.

Виховна функція реалізується через вплив навчального матеріалу, що сканується за допомогою QR-коду, на формування ціннісних орієнтирів учня, його естетичних смаків, адже за допомогою означеного засобу автори підручників подають текстовий матеріал, опрацювання якого спонукає школярів до роздумів, пошуку шляхів розв'язання порушеної в тексті проблеми, а також до обгрунтування власного вибору. Текстові ресурси QR-коду дають змогу учневі усвідомити мову як динамічну багатофункційну систему, упевнитися, що в мові зафіксовано і збережено результати людської діяльності, вербалізовано історичний досвід, переконатися, що досконале володіння мовою в майбутньому сприятиме життєвому й професійному становленню. Рефлексійна функція QR-коду полягає в тому, що учень, виконуючи те чи інше 
завдання, має змогу перевірити правильність своїх дій, проаналізувати результати й окреслити шляхи самостійного підвищення рівня знань, сформованих умінь і навичок.

Контрольна функція QR-коду уможливлює оперативне отримання вчителем відомостей про якість виконання завдань учнями, рівень засвоєння змісту навчання. Це дає змогу відразу внести корективи в освітній процес.

Усі означені функції становлять цілісну систему й реалізуються лише в тісному взаємозв'язку одна $з$ одною. Крім того, зазначимо, що система функцій є системою відкритою і динамічною, оскільки може змінюватися відповідно до педагогічної парадигми й соціального замовлення.

Мета статті - визначити та схарактеризувати функції QR-кодів як складника підручників української мови, експериментально перевірити результативність застосування QR-кодів в освітньому процесі.

\section{2. МЕТОДИКА ДОСЛІДЖЕННЯ}

У дослідженні використано такі методи: теоретичний аналіз наукової літератури з порушеної проблеми, що дав змогу уточнити основні поняття дослідження; систематизувати й узагальнити навчально-методичні ідеї з проблем застосування QRкодів у структурі шкільних підручників; узагальнення педагогічного досвіду вчителівпредметників, що сприяли виокремленню й обгрунтуванню функцій QR-кодів як складника підручника; структурно-функціональний, системний аналіз; проєктування кодів для підручників української мови; анкетування учнів і вчителів, педагогічний експеримент; метод обрахунку статистичних даних «критерій однорідності хі-квадрат»; інтерпретування результатів дослідницької роботи.

\section{3. РЕЗУЛЬТАТИ ДОСЛІДЖЕННЯ}

Як свідчить аналіз навчальних видань 3 різних шкільних предметів, за допомогою QR-коду учні швидко можуть знайти потрібні відомості в інтернеті, як, наприклад, електронні словники - орфоепічні, орфографічні, тлумачні, фразеологічні, перекладні тощо. Але в процесі розроблення змісту шкільних підручників, зокрема української мови профільного рівня для 9-11 класів, ми переконалися в необхідності виокремлення спеціальних матеріалів для подальшого зчитування їх учнями за допомогою QR-кодів. Це зумовлено кількома чинниками: по-перше, потребою подати значний обсяг інформації, що викликано вимогами чинної програми й обмеженим обсягом підручника; по-друге, метою й завданнями курсу, що передбачає «формування інтелектуально розвиненої, морально досконалої, національно свідомої, духовно багатої мовної особистості, яка вільно володіє виражальними засобами сучасної української літературної мови, іiї стилями, різновидами, жанрами в усіх видах мовленнєвої діяльності (аудіювання, читання, говоріння, письмо), відзначається активною громадською позицією, готовністю до подальшого професійно орієнтованого навчання, спроможна самостійно визначати цілі самонавчання, самовиховання й саморозвитку та дієво їх реалізовувати» [9]; по-трете, необхідністю включення матеріалів, орієнтованих на підготовку учнів до ЗНО; по-четверте, потребою залучення учнів до самостійної дослідницької роботи, оскільки вчені (О. Малихін, І. Нагрибельна, С. Омельчук та ін.) доводять доцільність урахування принципу стимулювання самоосвіти й самостійності в навчанні. Витоки цієї настанови знаходимо в працях А. Дістервега: «Розвиток і освіта жодній людині не можуть бути загадані чи 
повідомлені. Будь-хто, хто бажає до них залучитися, повинен досягнути цього власною діяльністю, власними силами, власним напруженням...» [10, с.221].

Для перевірки ефективності застосування QR-кодів було проведено педагогічний експеримент на базі Київської школи I-III ступенів № 9, Київської спеціалізованої школи 3 поглибленим вивченням української мови та літератури № 252 імені Василя Симоненка та Бердянської спеціалізованої школи I-III ступенів №16 з поглибленим вивченням іноземних мов Бердянської міської ради Запорізької області. Мета експерименту полягала в перевірці доцільності долучення QR-кодів до структури підручників української мови (профільний рівень) та визначенні їх можливостей у формуванні предметної компетентності учнів, на що, власне, й спрямовано вивчення предмета. Хоч зміст QR-кодів має забезпечувати паралельне формування предметної й ключових компетентностей учнів, оскільки це процес органічний і взаємопов'язаний, у статті ми обмежилися вимірюванням динаміки сформованості предметної компетентності учнів, оскільки результати моніторингу сформованості десяти ключових компетентностей важко відобразити в межах обраного для оприлюднення жанру.

Експеримент було проведено упродовж 2018-2019 навчального року. До нього було залучено 153 учні та 4 вчителів-словесників. Перед початком експерименту було сформульоване припущення, що використання розроблених матеріалів, репрезентованих засобами QR-кодів у процесі навчання української мови, сприятиме формуванню в здобувачів освіти предметної і ключових компетентностей. Для підтвердження висунутої гіпотези було розв'язано такі завдання: визначено стартовий рівень сформованості предметної компетентності учнів; проведено експериментальне навчання з використанням розроблених QR-кодів; проаналізовано його результати.

Для проведення педагогічного експерименту учнів було поділено на експериментальні й контрольні класи. В експериментальних класах, крім традиційного паперового підручника, систематично застосовувались QR-коди, які учні сканували за допомогою смартфонів. У контрольних класах означений засіб навчання не використовували.

Матеріали, розміщені на QR-кодах, були орієнтовані на формування предметної компетентності учнів.

Експериментальна перевірка передбачала два зрізи: діагностичний та контрольний. До початку експерименту результати діагностичного зрізу уможливили висновок, що учні експериментальних і контрольних класів (далі - ЕК і КК) мають приблизно однакові рівні сформованості предметної компетентності. Покажемо це діаграмою.

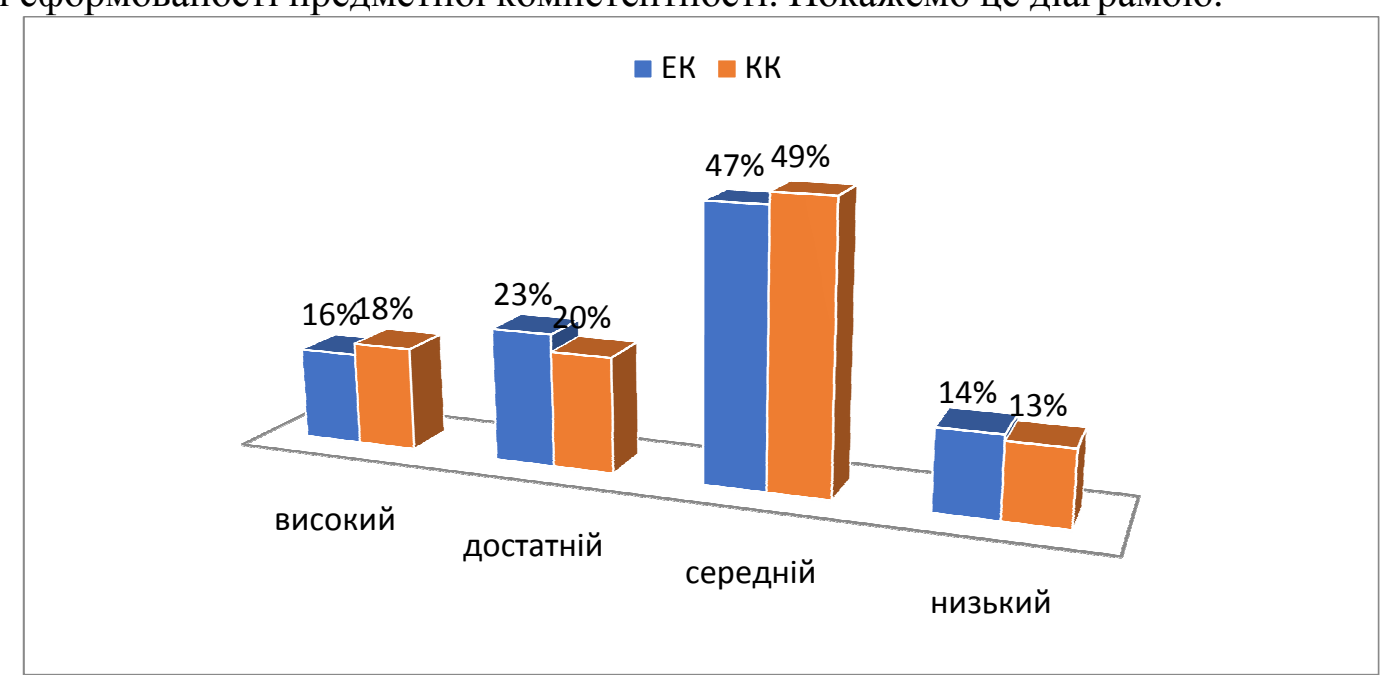

Рис. 1. Результати виконання учнями діагностичного зрізу 
Учні експериментальних класів систематично залучалися до роботи з QR-кодами, якими передбачено опрацювання теоретичних відомостей, що розширюють зміст підручника, виконання дослідницьких завдань, які спонукають учнів до спостереження над мовою, тестових завдань задля з'ясування рівнів засвоєння матеріалу, сформованості умінь і навичок.

Для учнів старших класів самостійна діяльність - один із основних видів навчальної роботи, тому успіх залежить від методично правильної організації активної діяльності їх у процесі навчання української мови. На нашу думку, одним із засобів самоконтролю освітньої діяльності здобувачів освіти є тести, самостійне виконання яких дасть змогу учням перевірити рівень власних знань з мови, визначити теми для повторення.

Проведене анкетування вчителів-словесників засвідчило, що 92\% респондентів вважають тести обов'язковим складником підручника. Це зумовлено пріоритетністю означеного засобу під час зовнішнього незалежного оцінювання (далі - ЗНО). 3 огляду на це структурним складником підручника «Українська мова» для 10 класу (профільний рівень) стали 19 QR-кодів, 10 з яких містять тестові завдання, виконання яких дасть учням змогу самостійно перевірити власний рівень знань, умінь і навичок 3 української мови, тобто реалізують контрольну й рефлексійну функції. [11].

Складені завдання становлять комплекс різних за типом тестів, максимально наближених до пропонованих ЗНО: перші 8 завдань типу «множинний вибір - єдина відповідь» передбачають вибір однієї правильної відповіді з п'яти варіантів.

За типом «відповідність» побудовані 9-12 завдання, що передбачає пошук відповідності між мовним явищем і прикладом.

Застосування тестових завдань у підручнику було схвалено десятикласниками: 95 \% зазначили, що їм подобається виконувати тести, уміщені на QR-кодах, бо так вони мають змогу відразу отримати відповідь і побачити, чи впоралися 3 завданням. Важливу роль в освітньому процесі мали завдання, що передбачали стилістичний експеримент, наприклад, уставляння учнями мовних одиниць замість пропущених авторських, добір потрібного за змістом синоніма 3 низки запропонованих, зміна часової форми дієслова тощо.

Так, наприклад вправа № 97 містить QR-код, що дає змогу учням швидко відсканувати художні тексти (поетичний опис бабиного літа Н. Лівицької-Холодної та прозовий опис цієї ж пори року С. Гуцала) і виконати завдання, що передбачає спостереження учнів над мовою творів, визначення стилістичної ролі звукопису на текстовому матеріалі [11].

Учні, виконавши завдання, мали змогу відсканувати через QR-код оригінальний текст, порівняти свій варіант з авторським, зробити висновки про доцільність уживання того чи того слова.

Кількісні показники рівнів сформованості предметної компетентності учнів на констатувальному та прикінцевому етапах формувального експерименту значно підвищилися в ЕК. Водночас у КК показники змінилися незначно. Так, на 9,9\% збільшилася кількість учнів ЕК із високим рівнем (у КГ на 2,9\%); на 35,4\% - 3 достатнім рівнем (у КК - на 3,6\%). Тим часом на 12,1\% зменшився показник середнього рівня в ЕК (у КК на 1,8\%); на 33,2\% зменшився показник низького рівня в ЕК (у КК на 4,7\%). 


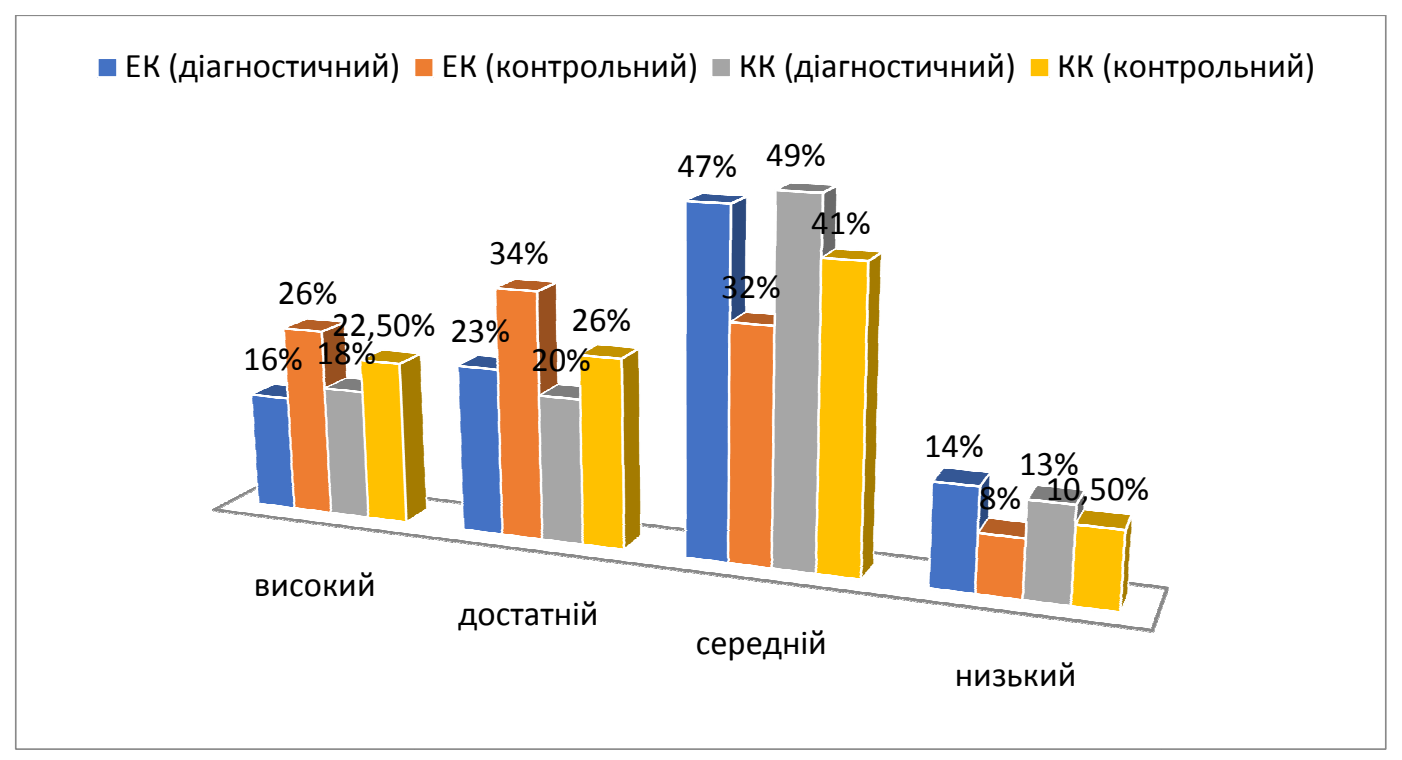

Рис. 2. Зіставні результати виконання учнями діагностичного й контрольного зрізів

Метою опрацювання результатів формувального експерименту за допомогою критерію однорідності $\chi^{2}$ було встановлення розбіжності кінцевого стану рівня сформованості предметної компетентності учнів ЕК і КК.

Для статистичного оброблення експериментальних даних ми обрали методику визначення достовірності співпадіння та розбіжностей для експериментальних даних, що було виміряно за допомогою порядкової шкали. Важливою стала наукова позиція Д. Новикова, що для експериментальних даних, які були виміряні за допомогою порядкової шкали, доцільно використовувати критерій однорідності хі-квадрат, емпіричне значення якого вимірюється за спеціальною формулою [12].

У загальному вигляді сутність цього методу полягає в тому, що початкові (до початку експерименту) стани експериментальної та контрольної груп (у нашому випадку - ЕК і КК) збігаються, а прикінцеві - навпаки - розрізняються. Відтак, можна зробити висновок про те, що ефект змін зумовлений саме реалізацією експериментальної методики, яка передбачала застосування QR-кодів. Таким чином, за результатами оброблення експериментальних даних зможемо довести ефективність застосування QR-кодів як складника підручника української мови.

Маємо порядкову шкалу $(\mathrm{L}=4)$ з різними рівнями - «високий рівень», «достатній рівень», «середній рівень» та «низький рівень». Характеристикою класу $є$ відсоток учнів, які продемонстрували певний рівень. Для учнів ЕК вектор рівнів $€ \mathrm{n}=(\mathrm{n} 1, \mathrm{n} 2, \mathrm{n} 3$, $\mathrm{n} 4)$, де ${ }^{n_{k}}$ - відсоток учнів на $\mathrm{k}$-му рівні, $\mathrm{k}=1,2,3,4$. Для учнів КК вектор рівнів $\epsilon \mathrm{m}$ $=(\mathrm{m} 1, \mathrm{~m} 2, \mathrm{~m} 3, \mathrm{~m} 4)$, де $m_{k}$ - відсоток учнів на $\mathrm{k}$-му рівні, $\mathrm{k}=1,2,3,4$.

Розрахунок емпіричного значення $\chi^{2}$ на прикінцевому етапі експерименту здійснювався за такою формулою.

$8,0), \mathrm{m}=(8,1 ; 17,4 ; 37,9 ; 36,6)$.

$$
\chi_{\text {eмn } \phi}^{2}=N \cdot M \cdot \sum_{i=1}^{L} \frac{\left(\frac{n_{i}}{N}-\frac{m_{i}}{M}\right)^{2}}{n_{i}+m_{i}} \text {, де } \mathrm{N}=100, \mathrm{M}=100, \mathrm{~L}=4, \mathrm{n}=(14,8 ; 48,7 ; 28,5 ;
$$


Емпіричне значення критерію $\chi^{2}$ на прикінцевому етапі експерименту $\chi_{\text {eмn } \phi}^{2}=$ 36,45 , що значно більше за критичне значення $\chi_{0,05}^{2}=7,82$. Відтак, достовірність розбіжностей характеристик експериментального та контрольного класів стосовно рівня сформованості предметної компетентності учнів після формувального експерименту складає 95\%.

Оброблення експериментальних даних статистичними методами (емпіричне значення критерія Пірсона $\chi^{2}$ більше за критичне) довела результативність здійсненого експерименту з імовірністю 95\%. Отже, можна стверджувати, що в процесі педагогічного експерименту доведено результативність застосування QR-кодів як складника підручника української мови.

Експеримент засвідчив методичну доцільність упровадження QR-кодів в освітній процес. 3 огляду на це було значно збільшено кількість QR-кодів у рукописі підручника української мови для 11 класу - до 68. Значна частина 3 них містить теоретичні відомості, що зумовлено особливостями чинної програми і необхідністю підготовки учнів до ЗНО [13].

Інтерактивні матеріали до підручників української мови 10 та 11 класів профільного рівня розміщено на сайті interactive.ranok.com.ua.

3-поміж матеріалів, винесених на QR-коди, значне місце посідають теоретичні відомості з риторики, граматики, правопису, спрямовані на формування предметної компетентності учнів з української мови. Для того щоб учні ознайомилися зі зразками виступів відомих людей-наших сучасників, - підручник містить покликання, за яким можна його прослухати або ж скориставшись QR-кодом, наприклад:

Прослухайте виступ мовознавия Павла Грищенка «Як досягти мовної гармонії у нашому суспільстві» за покликанням https://www.youtube.com/watch?v=rdsNouvSBJE або скориставшись QR-кодом.

Такі матеріали сприяють формуванню в учнів інтересу до предмета, виробленню стійких риторичних умінь.

Перегляньте передачу «Велич особистості» від 05.12.2016 року про Олександра Олеся за покликанням https://www.youtube.com/watch?v=_ kAudcCtN1M або скориставшись $Q R$-кодом. Запишіть тези інтерв'ю.

Самостійне прослуховування учнями виступів, перегляд телепередач, відеороликів сприяє кращому зануренню в тематику, уможливлює роботу в зручному для старшокласників темпі в зручний час, а також кількаразове прослуховування чи перегляд, що складно зробити в класі під час організації колективної роботи. До QRкодів учні можуть звертатися й під час уроку, наприклад, виконуючи вправу № 170:

Ознайомтеся із фрагментом інтерв'ю Ірини Снітинської, засновниці «Школи риторики й ораторства АГРУС» у Львові.

Звичайно, у межах вправи не було змоги подати повністю інтерв'ю, що має не тільки значний інформаційний, а й виховний потенціал для учнів, тому одне 3 післятекстових завдань вправи було сформульовано так: Якщо вас зацікавив досвід успішної жінки, ознайомтеся з інтерв'ю за покликанням http://dilove.coт.иа/іринаснітинська-тепер-я-знаю-що- можу/ або скориставшись $Q R$-кодом.

Уведення подібних завдань сприяє опануванню учнями правил ефективного спілкування, засвоєнню вербальних формул українського мовленнєвого етикету, а також забезпечує реалізацію мотиваційної й розвивальної функцій QR-коду, сприяючи створенню позитивного емоційного тла, зацікавленню учнів предметом, формуванню в учнів упевненості в досягненні очікуваних результатів, стійкого бажання навчатися, розвиткові лінгвокреативності. 
QR-коди сприяли заощадженню навчального часу на уроці, оскільки за їх допомогою учні швидко знаходили необхідні відомості й відразу бралися до виконання завдань.

Зміст чинної програми орієнтує в 11 класі на пріоритетність підготовки учнів до складання ЗНО. Це й зумовило виокремлення спеціального розділу підручника, який містить понад $50 \mathrm{QR}$-кодів, що нагадують учням теоретичні відомості з усіх розділів шкільної програми, правила написання слів разом, окремо, через дефіс, правила вживання розділових знаків тощо. Такий вибір зумовлений потребами учнів і запитами вчителів - у разі необхідності кожен одинадцятикласник може звернутися до того навчального матеріалу, який йому потрібно повторити.

Експеримент переконав, що важливо адекватно розкрити мовознавчу теорію у змісті i підручника, i QR-коду, уникаючи дублювання його, ілюструючи цікавими, комунікативно значущими прикладами. Певна частина QR-кодів у рукописі підручника покликана забезпечувати електронну підтримку учнів у процесі виконання окремих вправ.

Ha QR-коди було винесено тестові завдання для учнів, правильні варіанти девіантних текстів, запропонованих для редагування. Це дає змогу старшокласникам швидко перевірити результати власної діяльності, проаналізувати свою роботу, визначити самостійно напрями подальшої самоосвітньої діяльності. Так зреалізовано рефлексійну функцію QR-кодів.

Добір теоретичного матеріалу з огляду на його характер у рукописах підручників здійснено за різними критеріями: уникнення надлишковості й додавання важливої інформації, пріоритетності адекватного відображення дійсності, комунікативної значущості повідомлюваного, його ролі у формуванні ключових та предметної компетентностей учнів, новизни, доступності, емоційності. Урахування таких критеріїв, зокрема, потребує тема «Переклад текстів різних стилів, типів і жанрів мовлення», у процесі опрацювання якої учень (учениця) має виявити сформовані вміння зберегти авторську думку під час перекладу. Оскільки в українських школах учні опановують різні іноземні мови (англійську, німецьку, французьку, іспанську), до того ж правом вивчення рідної мови в школі користуються національні меншини (болгари, угорці, греки, євреї, кримські татари, румуни, роми та ін.), у підручнику неможливо подати тексти для перекладу всіма означеними мовами. Тому вважаємо за доцільне в межах теми подати для перекладу тексти англійською та російською мовами 3 огляду на те, що їх опановує найбільша кількість учнів, а тексти іншими мовами винести на QR-коди задля уникнення надлишковості. Таке розміщення навчального матеріалу уможливить дотримання вимог до обсягу підручника й водночас розширити його інформаційний потенціал. Отже, інформаційні матеріали, вміщені на QR-коди, розширюють і поглиблюють інформацію, подану в традиційних підручниках, сприяють формуванню предметної компетентності учнів, виконують функцію контролю.

\section{4. ВИСНОВКИ ТА ПЕРСПЕКТИВИ ПОДАЛЬШИХ ДОСЛІДЖЕНЬ}

Застосування QR-кодів як складника шкільних підручників $є$ перспективним, оскільки означений засіб навчання сприяє підвищенню в учнів мотивації до опанування предмета, розширенню, збагаченню й поглибленню змісту навчання, що уможливлює застосування в освітньому процесі диференційованих завдань. До того ж застосування QR-коду дає змогу учням самостійно виконати певні завдання задля перевірки рівня сформованості знань, умінь і навичок та швидко отримати результат. Поява QR-кодів, їх швидке поширення сприяє оновленню дидактичного матеріалу, його візуалізації, забезпечує аудіопідтримку.

Методично доцільне включення QR-кодів в освітній процес сприяє інтенсифікації самостійної діяльності учнів, активізації їхньої пізнавальної активності, 
індивідуалізації навчання. Водночас важливо спрямовувати здобування навчальної інформації за допомогою QR-кодів, забезпечуючи іiі актуальність, доступність, емоційність. Розроблення QR-кодів у структурі сучасних підручників допомагає зробити навчання української мови ефективним і цікавим.

У дослідженні визначено функції QR-кодів у структурі підручників української мови для учнів старших класів (профільний рівень), з'ясовано принципи відбору інформації для них, розроблено зміст навчальних матеріалів для наповнення QR-кодів у підручнику для учнів 11 класу на компетентнісних засадах..

Водночас констатуємо, що одним зі шляхів розширення можливостей освітнього процесу є застосування потенціалу QR-коду в організації самостійної роботи учнів, зокрема під час виконання міжпредметних проєктів та інших видів робіт. До того ж потребує спеціального дослідження вплив означеного засобу на формування ключових компетентностей учнів. на що й будуть спрямовані наші подальші пошуки.

\section{СПИСОК ВИКОРИСТАНИХ ДЖЕРЕЛ}

[1] С. Караман, та В. Тихоша, «Технологія створення підручників і посібників для поглибленого вивчення української мови в гімназії», Дивослово, №4, с. 36-38, 2001.

[2] В. Редько, Конструювання змісту шкільних підручників з іноземних мов: теорія і практика, Київ, Україна: Педагогічна думка, 2017.

[3] Рекомендації ЮНЕСКО щодо політики в сфері мобільної освіти. [Електронний ресурс]. Доступно: http://iite.unesco.org/pics/publications/ru/files/3214738.pdf.

[4] В. Бузько, та Ю. Счкало, Можливості використання QR-кодів у навчанні фізики. [Електронний ресурс]. Доступно: https://arxiv.org/ftp/arxiv/papers/1808/1808.04211.pdf Дата звернення : Травень 03, 2019.

[5] I. Галузо, та А. Лукомський, Использование технологии QR-кодов в образовательной деятельности. [Електронний pecypc]. Доступно: https://lib.vsu.by/xmlui/bitstream/handle/123456789/13756/3339.pdf? sequence=1\&isAllowed=y. Дата звернення : Червень 11, 2019.

[6] О.П. Сергєєнкова, та Ф.М. Подшивайлов, «Психологічні чинники розвитку мотиваційної сфери особистості сучасного студента», Актуальні проблеми психології. т.12. Психологія творчості. С. 260276, 2016.

[7] О. В. Малихіна, Мотивачія учіння молодших школярів, Київ, Україна: Навч. кн., 2002.

[8] Г. Граник, С. Бондаренко, и И. Якиманская, «Психологические основы создания школьных учебников», в Московская психологическая школа : История и современность : В 3 т., В. Рубцова, Ред., Москва, Россия: ПИ РАО, МГППУ, т.1, с. 268-287, 2004.

[9] Л. Мацько, Т. Груба, О. Семеног, та Т. Симоненко, «Українська мова 10-11 класи, Програма для профільного навчання учнів загальноосвітніх навчальних закладів», Інформаиійний збірник та коментарі Міністерства освіти і науки Украӥни, № 12, с. 3-73, 2017.

[10] А. Дистервег, Избранные педагогические сочинения, Москва, СССР : Учпедгиз, 1956.

[11] С. Караман, О. Горошкіна, О. Караман, та Л. Попова, Українська мова (профільний рівень) : підручник для 10 класу закладів загальної середньої освіти, Харків, Україна : Ранок, 2018.

[12] Д. А. Новиков, Статистические методы в педагогических исследованиях (типовые случаи). Москва, Россия : МЗ-Пресс, 2004.

[13] С. Караман, О. Горошкіна, О. Караман, та Л. Попова, Украӥнська мова (профільний рівень) : підручник для 11 класу закладів загальної середньої освіти, Харків, Україна : Ранок, 2019.

Матеріал надійшов до редакиії 02.09. 2019 p.

\section{ФУНКЦИИ QR-КОДОВ В СТРУКТУРЕ УЧЕБНИКА УКРАИНСКОГО ЯЗЫКА}

\section{Горошкина Елена Николаевна}

доктор педагогических наук, профессор, ведущий научный сотрудник отдела профильного обучения Института педагогики НАПН Украины, г.Киев, Украина

ORCID ID 0000-0002-0378-888X

olenagoroshkina@gmail.com 


\title{
Греб Мария Михайловна
}

доктор педагогических наук, профессор, заведующая кафедрой украинского языка и славистики Бердянский государственный педагогический университет, г. Бердянск, Украина

ORCID ID 0000-0003-2874-7985

marygreb@i.ua

\section{Горошкин Игорь Александрович}

кандидат педагогических наук, старший научный сотрудник отдела обучения иностранных языков Институт педагогики НАПН Украины, г. Киев, Украина

ORCID ID 0000-0003-2964-458X

igorgoroshkin@gmail.com

\section{Караман Станислав Александрович}

доктор педагогических наук, профессор, заведующий кафедрой украинского языка

Киевский университет имени Бориса Гринченка, г. Киев, Украина

ORCID ID 0000-0003-3186-375X

stanislavkaraman@gmail.com

\begin{abstract}
Аннотация. В статье рассмотрена проблема использования QR-кодов как составляющей современного учебника. Обоснована актуальность введения QR-кодов в содержание учебников украинского языка. Уточнено определение QR-кода, под которым определен компактный носитель учебной информации объемом около трех тысяч байт, закодированной с помощью специальных программ или сервисов и графически представленной как черно-белый или цветной квадрат. Установлено, что QR-код позволяет расширение и углубление теоретических сведений по учебному предмету. В учебниках украинского языка материалы, представленные на QR-кодах, расширяют и углубляют теоретические сведения и дидактический материал традиционных учебников, способствуют совершенствованию орфоэпических, орфографических, пунктуационных умений и навыков учащихся, выполняют функцию контроля, предлагая тестовый и другой материал для установления уровня сформированности знаний, умений и навыков учащихся. Определены и обоснованы функции QR-кодов - мотивационная, информационная, развивающая, воспитательная, рефлексивная, контрольная. Осуществлен анализ содержания учебников украинского языка для 10 класса и рукописи учебника для 11 класса, содержащих QR-коды. Приведены сведения об экспериментальной проверке эффективности применения QRкодов, в процессе которой учащиеся экспериментальных классов систематически привлекались к работе c QR-кодами, помещенными в учебнике украинского языка, представляющие теоретические сведения, которые расширяли и углубляли содержание учебника; выполнение творческих, исследовательских задач, побудивших учащихся к наблюдениям над языком, а также упражнений на редактирование, тестовых заданий. Определены принципы отбора теоретического материала для QR-кодов, к которым отнесены доступность материала, его коммуникативная значимость, новизна, эмоциональность, роль в формировании предметной и ключевых компетентностей учащихся. Приведены конкретные примеры кодирования информации в учебниках украинского языка: теоретических сведений, материалов средств массовой информации (интервью, телепередач, выступлений) для анализа их учащимися, тестовых заданий, примеров правильных соответствий девиантным текстам, предлагаемых учащимся для редактирования и тому подобное.
\end{abstract}

Ключевые слова: QR-код, учебник украинского языка; средства обучения; применение QR-кода; функции QR-кодов; принципы отбора информации для QR-кодов; образовательный процесс; учащиеся старших классов. 


\title{
FUNCTIONS OF QR-CODES IN THE STRUCTURE OF UKRAINIAN LANGUAGE TEXTBOOKS
}

\author{
Olena M. Goroshkina \\ Doctor of Pedagogical Sciences, Professor, Leading Researcher at the Department of Profile Education \\ Institute of Pedagogy of the NAES of Ukraine, Kyiv, Ukraine \\ ORCID ID 0000-0002-0378-888X \\ olenagoroshkina@gmail.com
}

Mariia M. Hreb

Doctor of Pedagogical Sciences, Professor, Head of the Department of Ukrainian Language and Slavic Studies Berdyansk State Pedagogical University, Berdyansk, Ukraine

ORCID ID 0000-0003-2578-2865

marygreb@i.ua

Igor O. Goroshkin

PhD of Pedagogical Sciences, Senior Researcher at the Department of Foreign Languages

Institute of Pedagogy of the NAES of Ukraine, Kyiv, Ukraine

ORCID ID 0000-0003-2964-458X

igorgoroshkin@gmail.com

\author{
Stanislav O. Karaman \\ Doctor of Pedagogical Sciences, Professor, Head of the Department of Ukrainian Language \\ Borys Grinchenko Kyiv University, Kyiv, Ukraine \\ ORCID ID 0000-0003-3186-375X \\ stanislavkaraman@gmail.com
}

\begin{abstract}
In the article, the issue of implementing QR-codes as a component of a modern textbook is considered. The relevance of introducing QR-codes into the content of Ukrainian language textbooks is substantiated. The definition of a QR-code as a compact carrier of educational data, amounting to about 3,000 bytes, encoded with special programmes or services and represented graphically as a black-and-white or coloured square is elaborated. It is ascertained that QR-codes enable expanding and broadening the theoretical information on the subject. In Ukrainian language textbooks, the materials provided by QR-codes could extend and deepen theoretical data and teaching material contained in traditional textbooks, facilitate the improvement of orthoepic and grammar knowledge and spelling skills of students and perform the controlling function due to comprising tests and other materials to determine the level of students' knowledge and skills. The functions of QR-codes in the structure of Ukrainian language textbooks, notably motivational, informational, developmental, educational, reflexive and controlling, are defined and substantiated. The content of Ukrainian language textbooks with QR-codes for Grade 10 and the manuscript for the respective textbook for Grade 11 is reviewed. The data on the efficiency checking of the embedding of QR-codes are cited. In the course thereof the students of the experimental group were engaged in activities implying application of QR-codes in Ukrainian language textbooks on the regular basis. The assignments assumed acquisition of theoretical material which provided for expanding and broadening the content of the textbook and the fulfilment of creative and research tasks encouraging the students to observe the language and do text editing exercises and tests. The principles for the selection of theoretical material for the QRcodes, notably the availability of the material, its communicative significance, novelty, emotional appeal and its role in the development of the students' subject competency are designated. Specific examples of information coding in Ukrainian language textbooks are provided, namely, coding of theoretical information and media materials (interviews, TV programmes and speeches) for students to analyse, as well as tests and examples of correct analogues of deviant texts for students to edit, etc.
\end{abstract}

Keywords: QR-code; Ukrainian language textbook; teaching aids; application of QR-code; functions of QR-codes; educational process; students of senior grades. 


\section{REFERENCES (TRANSLATED AND TRANSLITERATED)}

[1] S. Karaman and V. Tykhosha, "The technology of creating textbooks and manuals for in-depth study of the Ukrainian language in the gymnasium," Dyvoslovo, no. 4, pp. 36-38, 2001. (in Ukrainian)

[2] V. Redko, Constructing the content of foreign languages school textbooks: theory and practice, Kyiv: ped. dumka, 2017. (in Ukrainian)

[3] UNESCO Recommendations on Mobile Education Policy. [Online]. Available: http://iite.unesco.org/pics/publications/ru/files/3214738.pdf Accessed on: Sept. 8, 2020.

[4] V. Buzko and Y. Yechkalo, "The potential of QR codes in teaching physics,", Nauk.zap., issue 10, part 1, pp. 112-118, 2016. (in Ukrainian)

[5] I. Haluzo and A. Lukomskiy, "QR codes in educational activities", Modern educ. in Vitebschina, no. 1, pp. 3339, 2018. (in Russian)

[6] O. P. Serhieienkova and F. M. Podshyvailov, "Psychological factors of the development of motivational sphere of a personality of a modern student," Akt. Probl. Psykh., vol. 12, issue "Psykholohiia tvorchosti," pp. 260-276, 2014. (in Ukrainian)

[7] O. V. Malykhina, Motivation of primary schoolchildren learning, Kyiv: Navch.kn., 2002. (in Ukrainian)

[8] G. Granik, S. Bondarenko and I. Yakimanskaya, "Psychological basis for the creation of school textbooks" in Moscow Psychological School: History and Present, vol. 1, V.Rubtsova, ed. Moscow: PI RAO, MGPPU, 2004, pp. 268-287. (in Russian)

[9] L. Matsko, T. Hruba, O. Semenoh and T. Symonenko, "Program for profile education of students of general educational institutions", Inf. collect. \& com. Ministry of Educ. and Sc. of Ukraine, no. 12, pp. 3-73, 2017. (in Ukrainian)

[10] A. Dysterveh, Selected pedagogical works, Moskow: Uchpedhyz, 1956. (in Russian)

[11] S. Karaman, O. Goroshkina O. Karaman and L. Popova, Ukrainian language (profile level): the $10^{\text {th }}$ grade textbook for institutions of general secondary education, Kharkiv: Ranok, 2018. (in Ukrainian)

[12] D. A. Novykov, Statistical methods in pedagogical research (reference cases), Moscow: MZ-Press, 2004. (in Russian)

[13] S. Karaman, O. Goroshkina, O. Karaman and L. Popova, Ukrainian language (profile level): the $11^{\text {th }}$ grade textbook for institutions of general secondary education, Kharkiv: Ranok, 2019. (in Ukrainian)

\section{(cc) BY-NC-SA}

This work is licensed under Creative Commons Attribution-NonCommercial-ShareAlike 4.0 International License. 